POLITYKA ENERGETYCZNA - ENERGY POLICY JOURNAL

$2021 \star$ Volume $24 \star$ Issue $3 \uparrow 93-102$

DOI: $10.33223 / \mathrm{epj} / 141096$

\title{
About the state and problems of standardization of energy management in Russian enterprises
}

ABSTRACT: The purpose of this article is to investigate the problematic aspects of standardization of energy management systems in Russian enterprises. The main characteristics of energy management, existing standards in the field of energy management are given. To study the best practices and the effectiveness of the implementation of the energy management system in 2017, the Ministry of Energy of Russia, with the participation of the Federal State Budgetary Institution "Russian Energy Agency" the Ministry of Energy of Russia, carried out the monitoring of energy efficiency management and the implementation of energy management systems in the practice of Russian companies. The peculiarity of the introduction of energy management systems in the practice of managing Russian enterprises has been identified, which consists in the fact that it occurs based on the already implemented quality management system, environmental management, labor protection, when a lot

$\triangle$ Corresponding Author: Ramilya Savchuk; e-mail: savchuk7722-1@tanu.pro

${ }^{1}$ Department of Quality Management, Russian University of Transport, Russia; ORCID iD: 0000-0002-8495-9547; e-mail: savchuk7722-1@tanu.pro

2 Department of Transport Construction in Extreme Conditions, Russian University of Transport, Russia; ORCID iD: 0000-0002-5015-4556; e-mail: cherkasov7722-1@delfttech.eu

3 Department of Quality Management, Russian University of Transport, Russia; ORCID iD: 0000-0001-5863-7715; e-mail: kondratiev7722-1@kaiost.cn

4 Department of Quality Management, Russian University of Transport, Russia; ORCID iD: 0000-0002-4467-8564; e-mail: matskepladze7722-1@uohk.com.cn

2021. The Author(s). This is an open-access article distributed under the terms of the Creative Commons Attribution-ShareAlike International License (CC BY-SA 4.0, http://creativecommons.org/licenses/by-sa/4.0/), which permits use, distribution, and reproduction in any medium, provided that the Article is properly cited. 
of work has been done (document management, internal audit system, corrective actions, training, provisions providing feedback and the possibility of submitting proposals, etc.). Like any quality management system, the successful implementation of this standard depends on the involvement of all levels and functions of the organization's management in this process, and especially on top management.

KEYWORDS: energy management system, energy efficiency, enterprises, industry, audit

\section{Introduction}

It is not a secret for anyone that the problem of the efficient use of all types of resources is one of the most urgent tasks of Russian industry. The implementation of the energy management system, the purpose of which is the efficient usage of energy resources, can significantly help to solve this problem. As all types of enterprises, organizations, companies and firms consume energy, this topic is extremely relevant and timely. Russian scientists and practitioners pay special attention to this topic in connection with the task of increasing the competitiveness of Russian enterprises (Antomoshkin 2017; Gorbunova and Puzina 2018; Gurevich and Primakova 2013; Redko and Furs 2020). Figure 1 shows the main goals, that gives energy management system.

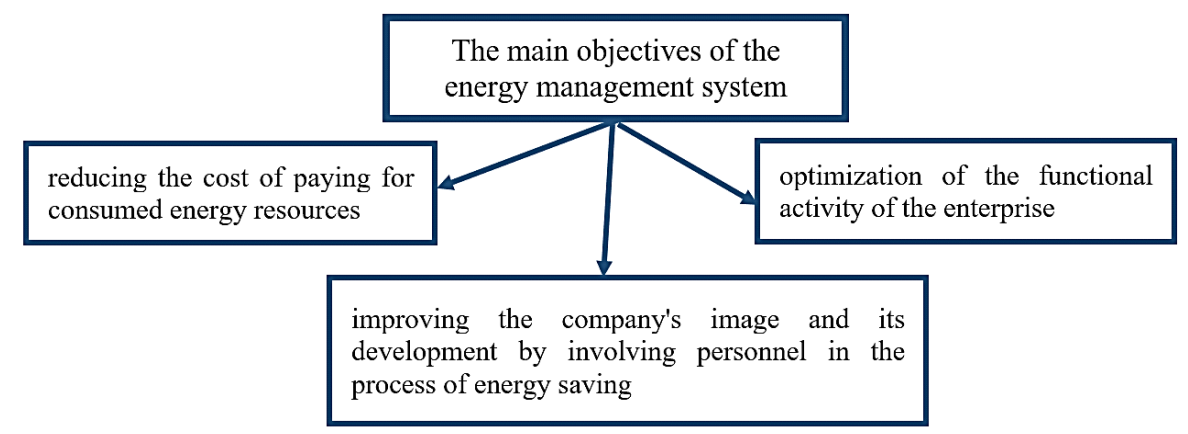

Fig. 1. The main goals of energy management system (GOST R 2008; ISO 2015; GOST R ISO 2019)

Rys. 1. Główne cele systemu zarządzania energią

The development of the energy management system was started in 2008 by the International Organization for Standardization (ISO). This international standard subsequently got the name ISO 50001 (Energy Management System - Requirements with instruction manual) (ISO 2014). The goal of the new standard was to provide enterprises with guidance on the process optimization of energy consumption and the systemic management of these processes. Of course, this 
standard was not developed from scratch. It was based on the American ANSI/MSE 2000: 2005 standard, the Korean KS A 4000: 2007 standard, and the standards of a number of European countries in the field of energy management. This standard has a lot in common with the European standard of the same name EN 16001: 2009, introduced in the summer of 2009, which now has national status in 19 European countries (Pareschi et al. 2020; Babenko 2020; Weiss et al. 2019; Somma et al. 2019; Kucher and Zamrii 2020).

The European standard is based on the methodology known as Plan - Do - Check - Act (or the PDCA cycle, in Russian - Plan - Perform - Check - Change). Following the European example, the British Standards Institute (BSI) issued document ВИР 2187: 2009 "Principles of Energy Management and Practice" in support, which has the status of "Publications for Information to Business". EN 16001: 2009 gives the possibility to carry out actions and procedures for energy conservation, but does not provide detailed and thorough guidance on what a manager should do in practice. An essential advantage of the ISO 50001 standard is its compatibility with the current standards of other management systems (MS), in particular: ISO 9001 and ISO 14001. That is why the standard is applicable for all types of enterprises of any industry affiliation and size. ISO 50001 can be used for certification like the standards of other management systems. The aim of this article is to investigate the problematic aspects of the standardization of energy management systems in Russian enterprises.

\section{The main features of the standardization of energy management}

The ISO 50001 standard establishes the requirements for an energy management system (EnMS) for the development and implementation of energy policies, setting goals, objectives, and an action plan for energy efficiency. In Figure 2 a diagram of an energy management system is shown.

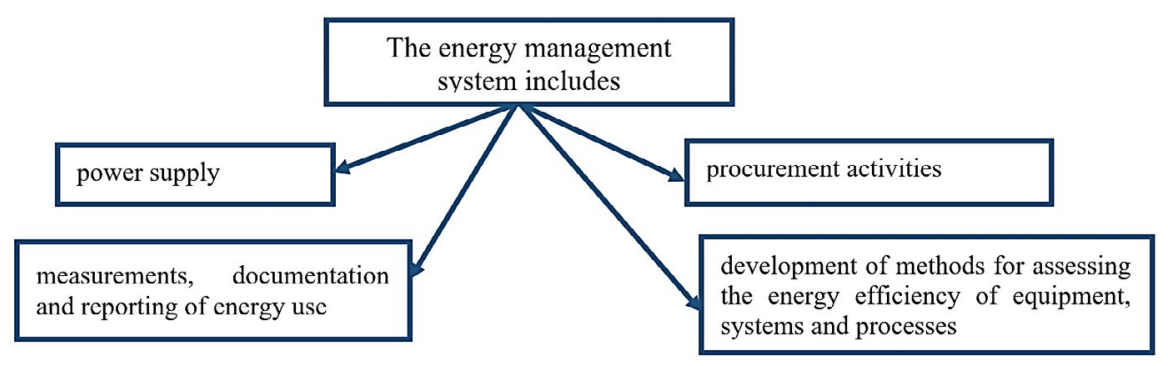

Fig. 2. Scheme of energy management system (Li and Strachan 2019)

Rys. 2. Schemat systemu zarządzania energią 
Based on the principle of PDCA, the ISO 50001 standard provides the possibility for continuous improvement and implementation of the basics of energy management in the practical activities of the enterprise. Let us therefore name the benefits of implementing this standard: improving the reliability of energy supply and energy security and competitiveness; financial cost reduction; system power management (Kachynska et al. 2021; Ihnatyshyn and Demian 2019).

Like any quality management system, the successful implementation of this standard depends on the involvement of all levels and functions of the organization's management in this process, and especially on top management. The requirements of ISO 50001 are in the form of prescriptions, without an exact indication of how to achieve this. The enterprise must define the way and method of achieving the objectives of this requirement by themselves. And what is important, the usage of energy management standards (EN 16001: 2009 and ISO/DIS 50001) promotes mutual understanding and interaction between all energy suppliers and consumers. Let us define the benefits that standardization of energy management will provide:

$\downarrow$ creating conditions for integrating energy efficiency into the enterprise management concept;

$\downarrow$ ensuring the most efficient usage of energy resources;

$\downarrow$ improvement of analysis, measurement, documentation, and reporting;

$\downarrow$ influence on greenhouse gas reduction (GHG);

$\downarrow$ energy management knowledge sharing;

$\downarrow$ introduction of best energy management practice and principles of energy-efficient behavior;

$\checkmark$ supply chain energy efficiency.

It should be mentioned that the central element of the energy management system, according to EN 16001: 2009 and ISO/DIS 50001, is the energy policy of the enterprise, which is defined and documented by the top management of the enterprise. The energy policy of the enterprise should: match the scope and boundaries of the energy management system; match the nature and extent of energy use; be compatible with the policies of other management systems (this is the only point that is not provided for in EN (16001:2009). Based on this, Figure 3 shows a model of energy management.

The next significant difference between the ISO/DIS 50001 project and the EN 16001: 2009 standard is the transition from the categories "energy aspect", "significant energy aspect" and the register of energy aspects to the concept of "energy profile of the organization". According to EN 16001: 2009, as well as in the Australian energy management system with a modified version of ISO 14000 plus, the company must identify and register its energy aspects as a matter of priority. In the process of creating an energy profile of an enterprise, it is necessary to identify past and current energy expenses in the course of the so-called "basic assessment". According to the project ISO/DIS 50001, an enterprise should introduce a documental procedure for the development and maintenance of its energy profile. The primary energy profile is the energy base for the appropriate period. According to this energy base, energy efficiency, i.e., changes in one direction or another should be identified.

According to the results of the basic assessment, the enterprise should identify its fixed assets, processes and personnel that are involved in energy consumption; establish energy efficien- 


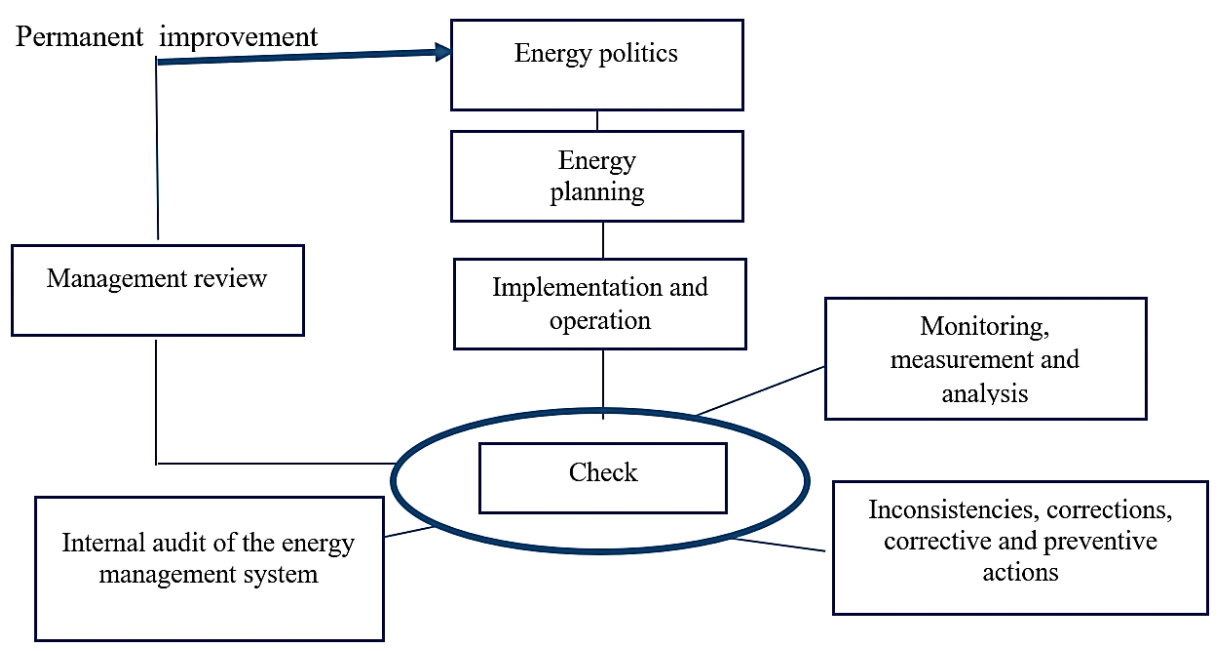

Fig. 3. A model of energy management: permanent improvement

Source: own study

Rys. 3. Model zarządzania energią: ciągłe doskonalenie

cy indicators (EEI) and the possibility of improving energy parameters. Of course, according to EN 16001: 2009 and ISO 50001, energy goals are a key element of the organization's energy management system and should be compatible with its energy policy and include commitments to improve energy efficiency.

\section{Stages and standards for the implementation of energy audit}

In European Directive 2006/32/EC of April 5, 2006, energy audit is defined as “... a systematic procedure to obtain adequate knowledge of the existing energy profile of a building or group of buildings, of an industrial operation and/or installation of a private or public service, identify and quantify costeffective energy savings opportunities, and report the findings" (State information system... 2019). According to the Russian law - “...energy inspection (energy audit) - the collection and processing of information on the usage of energy resources to obtain reliable information of the amount of energy resources used, energy efficiency indicators, identifying energy saving opportunities and improving energy efficiency with the reflection of the results in the energy passport" (Federal Law No. 261-FZ .. 2009). An energy audit is designed to provide a solution to the following tasks: making a map of energy usage; development of organizational and technical measures to reduce energy losses; definition of energy saving potential; financial evaluation of energy saving measures. 
Carrying out an energy audit goes through several stages. To implement an energy quality management system, in 2011, an ISO international organization developed the ISO 50001: 2011 standard "Energy Management Systems" (Gurevich and Primakova 2013). There are two ways of implementation of the ISO 50001 in Russia: direct usage and indirect usage. For direct usage, it is necessary to have a Russian version of the MS (as you know, Russian language is one of the official languages of ISO), public discussion of the project in Russia, availability of Russian versions (translations) of referenced MS. For the indirect usage of MS, three forms of development of GOST R (State Standard of the Russian Federation) are possible: identical, modified and nonequivalent with the introduction of appropriate changes to the documents (Weiss et al. 2021). Due to the lack of national standards for managing the energy efficiency of self-regulatory organizations (SROs), Russian enterprises are forced to develop and implement their standards governing the activities of all components of the system and their interaction (Lyalin and Pfayfer 2015).

The largest companies in the country currently fulfill projects to implement an energy management system based on the requirements of the international ISO 50001:2011 standard (GOST R ISO 50001-2012): AO “AK "Transneft", AO “KAMAZ", AO "NK "Rosneft", AO "RUSSETI", AO. "Sibur Holding”, OK "RUSAL”, AO "Surgutneftegaz", AO "LUKOIL”, AO "INTER RAO", GK "Rosatom", OAO "RGD”, GK "Gazprom neft", AO "MMK” and many others (Gorbunova and Puzina 2018). To study the best practices and the effectiveness of the implementation of the energy management system in 2017, the Ministry of Energy of Russia, with the participation of the Federal State Budgetary Institution "Russian Energy Agency" the Ministry of Energy of Russia, carried out the monitoring of energy efficiency management and the implementation of energy management systems in the practice of Russian companies (here and after referred to as the study). The results of the study are shown on Figure 4.

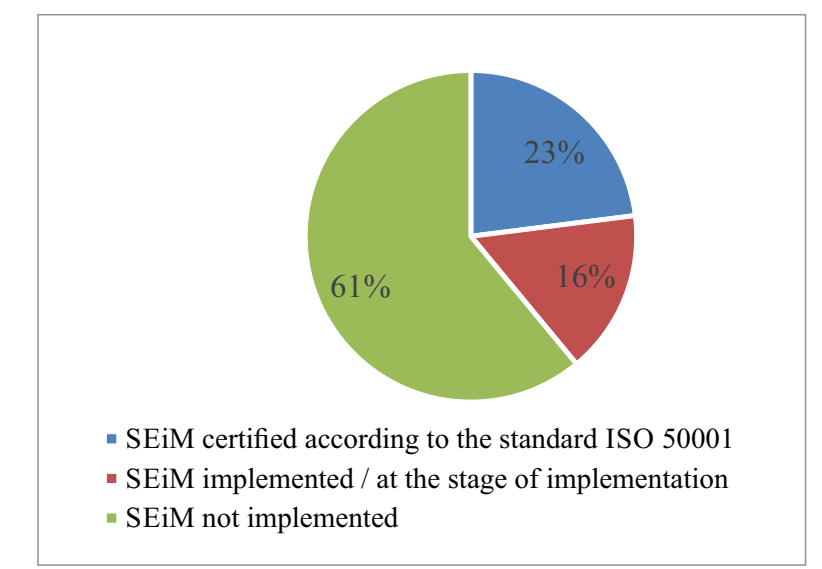

Fig. 4. Information on the share of companies among those surveyed and reporting information that implemented the energy management system (Pilipenko and Gladskikh 2014)

Rys. 4. Informacja o udziale firm wśród ankietowanych oraz raportowanie informacji, które z nich wdrożyły system zarządzania energią 


\section{Conclusions}

In this work for the first time by order of AO "Moscow United Energy Company" by the State Academy of Industrial Management named after N.P. Pastukhova (GAAPM - Yaroslavl) and the State Academy of Investment Specialists (GASIS - Moscow) a system of energy efficiency management standards was developed, which included basic energy management standards adapted to Russian conditions. The developed sets of standards included: guidelines (recommendations) for enterprises fulfilling effective energy management systems; the procedure for conducting the audit (energy audit and audit of energy management systems); requirements for bodies carrying out this audit, as well as requirements for the qualifications of personnel performing it. The benefits of the standardization of energy management were defined.

The energy policy of the enterprise should match the nature and extent of energy use. Russian enterprises are only at the beginning of introducing a system of energy management standards that will lead enterprises to a significant increase in energy efficiency, and thereby will increase the competitiveness of enterprises themselves, which, in turn, will increase the investment attractiveness of energy saving projects. That is why it is necessary to carry out the work to promote best practices in energy saving and introduce the best practices in the activities of Russian enterprises.

\section{References}

Antomoshkin, A.Yu. 2017. Experience in implementing an energy management system according to the UNIDO methodology in Russia. Cast and Metallurgy 4(89), pp. 143-147.

BABENKO, K.Y. 2020. Management of territorial economic development: project approach. Scientific Bulletin of Mukachevo State University. Series "Economics" 1(13), pp. 135-139.

Federal Law No. 261-FZ "On energy saving and on increasing energy efficiency and on amending certain laws of the Russian Federation". 2009. [Online] https://clck.ru/WGZc2 [Accessed: 2021-06-20].

Gorbunova, V.S. and Puzina, Ye.Yu. 2018. The effectiveness of the implementation of energy management systems in industrial companies in Russia. Transport Systems and Technologies 1, pp. 119-137.

GOST R 2008. GOST R 40.003-2008. Certification system GOST R. Register of quality systems. The procedure for certification of the quality management system for compliance with GOST R ISO 9001-2008 (ISO 9001: 2008). 2008. [Online] https://docs.cntd.ru/document/1200068716 [Accessed: 2021-06-20].

GOST R ISO 2019. GOST R ISO 19011-2003. Guidelines for auditing quality management systems and/ or environmental management system. 2019. [Online] http://base.consultant.ru/cons/CGI/online. cgi?req=doc;base=EXP; $=335887$ [Accessed: 2021-06-20].

Gurevich, V. and Primakova, I. 2013. Integration of energy management into the practice of managing the organization. Science and Innovation 12(26), pp. 5-7.

IhNATYShyn, M.V. and Demian, Y.Yu. 2019. Business-consulting as a tool for balancing business resources and management decisions at enterprises. Scientific Bulletin of Mukachevo State University. Series "Economics" 2(12), pp. 62-66. 
ISO 2014. ISO 50001: 2011 Energy Management Systems. Requirements and guidance for use. 2014. [Online] https://iso-management.com/wp-content/uploads/2018/09/ISO-50001-2011.pdf [Accessed: 2021-06-20].

ISO 2015. ISO 17021. Conformity assessment. Requirements for certification bodies of management systems. 2015. [Online] https://www.iso.org/obp/ui\#iso:std:iso-iec:17021:-1:ed-1:v1:ru [Accessed: 202106-20].

KachynsKa et al. 2021 - KachynSKa, N.F., Zemlyanska, O.V., Husiev, A.M., DemchuK, H.V. and KoVTUN, A.I. 2021. Labour protection as a component of effective management of a modern enterprise. Scientific Bulletin of Mukachevo State University. Series “Economics” 8(1), pp. 77-85.

KUCHER, L.R. and ZAMrII, O.M. 2020. The role of the competitive personality of the manager in management. Scientific Bulletin of Mukachevo State University. Series "Economics" 1(13), pp. 32-37.

Li, F. and Strachan, N. 2019. Take me to your leader: using socio-technical energy transitions (STET) modelling to explore the role of actors in decarbonisation pathways. Energy Research \& Social Science 51, pp. 67-81.

Lyalin, A.M. and PfaYfer, N.V. 2015. Energy management standardization in Russia. University Bulletin 9, pp. 197-202.

Pareschi et al. 2020 - Pareschi, G., KüNg, L., Georges, G. and Boulouchos, K. 2020. Are travel surveys a good basis for EV models? Validation of simulated charging profiles against empirical data. Applied Energy 275, DOI: 10.1016/j.apenergy.2020.115318.

PilipenKo, N.V. and GladSKIKH, D.A. 2014. Determination of the heat losses of buildings and structures by solving inverse heat conduction problems measurement techniques. Springer New York Consultants Bureau 2(57), pp. 181-186.

REDKO, K.YU. and FuRS, O.S. 2020. The current situation and world trends of green energy development Scientific Bulletin of Mukachevo State University. Series "Economics" 1(13), pp. 55-60.

Somma et al. 2019 - Somma, M.D., GRADiTi, G. and SiANO, P. 2019. Optimal bidding strategy for a DER aggregator in the day-ahead market in the presence of demand flexibility. IEEE Transactions on Industrial Electronics 66(2), pp. 1509-1519.

State information system in the field of energy conservation and energy efficiency. 2019. [Online] https:// gisee.ru/law/international/47502/ [Accessed: 2021-06-20].

Weiss et al. 2019 - Weiss, O., Pareschi, G., Schwery, O., Bolla, M., Georges, G. and Boulouchos, K. 2019. Long-term scheduling model of Swiss hydropower. $16^{\text {th }}$ International Conference on the European Energy Market (EEM) 1, DOI: 10.1109/EEM.2019.8916260.

Weiss et al. 2021 - Weiss, O., Pareschi, G., Georges, G. and Boulouchos, K. 2021. The Swiss energy transition: Policies to address the Energy Trilemma. Energy Policy 148, DOI: 10.1016/j.enpol.2020.111926. 


\section{O stanie i problemach standaryzacji gospodarki energetycznej w rosyjskich przedsiębiorstwach}

\section{Streszczenie}

W artykule omówiono problematyczne aspekty standaryzacji systemów zarządzania energią w rosyjskich przedsiębiorstwach. Podano główne cechy zarządzania energią, istniejące normy w zakresie zarządzania energią. W celu zbadania najlepszych praktyk i skuteczności wdrożenia systemu zarządzania energią w 2017 r. Ministerstwo Energii Rosji, przy udziale Federalnej Państwowej Instytucji Budżetowej „Rosyjska Agencja Energetyczna”, przeprowadziło monitoring zarządzania efektywnością energetyczną oraz wdrażania systemów zarządzania energią w praktyce rosyjskich firm. Zidentyfikowano specyfikę wprowadzenia systemów zarządzania energią w praktyce rosyjskich przedsiębiorstw. Polega ona na tym, że odbywa się to na podstawie już wdrożonego systemu zarządzania jakością, zarządzania środowiskowego, ochrony pracy (zarządzanie dokumentami, system audytu wewnętrznego, działania naprawcze, szkolenia, zapisy zapewniające informację zwrotną i możliwość składania wniosków itp.). Jak w przypadku każdego systemu zarządzania jakością, pomyślne wdrożenie tego standardu zależy od zaangażowania w ten proces wszystkich szczebli kierownictwa organizacji, a zwłaszcza najwyżej usytuowanych.

SŁOWA KLUCZOWE: efektywność energetyczna, audyt, transport, normalizacja, administracja 
